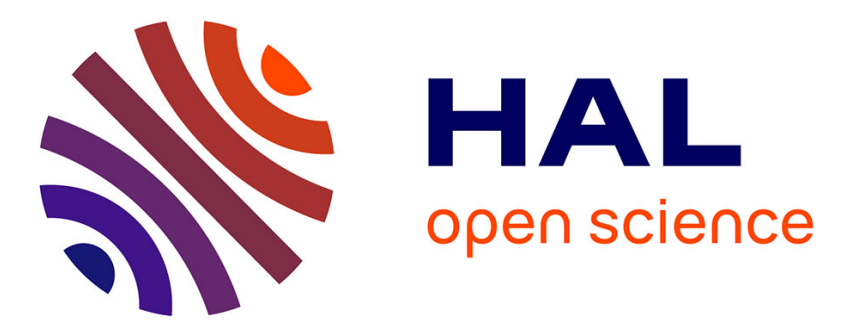

\title{
Methodological considerations when piloting an interview protocol: the example of Syrian asylum seekers in France \\ Inès Saddour
}

\section{- To cite this version:}

Inès Saddour. Methodological considerations when piloting an interview protocol: the example of Syrian asylum seekers in France. Journal of French Language Studies, 2020, 30 (2), pp.211-238. 10.1017/S0959269520000101 . hal-03356761

\section{HAL Id: hal-03356761 \\ https://hal-univ-tlse2.archives-ouvertes.fr/hal-03356761}

Submitted on 30 Sep 2021

HAL is a multi-disciplinary open access archive for the deposit and dissemination of scientific research documents, whether they are published or not. The documents may come from teaching and research institutions in France or abroad, or from public or private research centers.
L'archive ouverte pluridisciplinaire HAL, est destinée au dépôt et à la diffusion de documents scientifiques de niveau recherche, publiés ou non, émanant des établissements d'enseignement et de recherche français ou étrangers, des laboratoires publics ou privés. 


\section{Methodological considerations when piloting an interview protocol: the example of Syrian asylum seekers in France}

\section{Inès Saddour (URI Octogone-Lordat)}

\section{Abstract}

This article discusses some methodological issues that arose when analysing data collected in a pilot study of the SOFRA project. We aimed at piloting a semi-structured interview protocol designed to collect qualitative data with nine Syrian asylum seekers and refugees studying French at university, using an interview schedule that targeted, among other things, information about learners' interaction opportunities and attitudes about their new environment and learning experiences. Analysing the manners in which the interviewer asked the questions and coped with comprehension difficulties, as well as the way the interviewees responded to the questions, led to the identification of a number of problems that are partly related to question type and wording. The article concludes with a reflection on how to elicit relevant answers during a semi-structured interview with migrant learners.

\section{Introduction}

In a context where Europe is experiencing one of the most critical refugee crises of the post WWII era, researching how immigrant learners acquire a second language (L2) is more vital than ever. Syria is one of the 
main countries of origin of the asylum requests in France (3249 in 2017) ${ }^{1}$ These immigrants are faced with many new life challenges, the most crucial of which is learning French for a better integration and adaptation to their new environment and culture. Learning how to speak and write French in a relatively short time is a major concern for asylum seekers and refugees since it is the first condition of their access to training, work and accommodation. The acquisition of French for these individuals can take place in numerous ways, including the possibility to enrol in French courses at French universities. Indeed, since September 2017, the number of immigrants from the Middle East who have filed for asylum in France and have been allowed to enrol in such courses has risen constantly ${ }^{2}$. In order to serve this population, it is urgent to contribute to facilitating their integration in the French university and in the host society in general. In fact, understanding the needs of this relatively new learner profile at the university and being able to respond to those needs would make learning and teaching experiences more enjoyable and teaching practices more efficient. Additionally, investigating the processes underlying French language acquisition by Syrian immigrants would certainly contribute to better understanding of second language

\footnotetext{
${ }^{1}$ According to the French Office of protection of refugees and stateless persons (l'Office français de protection des Réfugiés et des Apatrides (OFPRA)) https://www.ofpra.gouv.fr/fr/l-ofpra/actualites/les-donnees-de-l-asile-2017-a-l.

2 According to the DILAMI report (Sourisseau, 2018)
} 
acquisition (SLA) in general and the acquisition of French by Arabic speakers, in particular.

This article aims at discussing a number of methodological considerations that arose in a pilot study ${ }^{3}$ conducted as part of a bigger project SOFRA: Approche SOcioculturelle et psychologique de l'acquisition du FRAnçais par des demandeurs d'asile syriens. These considerations are related to conducting interviews with Syrian beginner and intermediate learners of French L2. In particular, we examine how the interviewer asked questions in semi-structured interviews and we discuss the methodological problems that learners' responses reveal about the interview protocol. The aim of this study is to improve the interview schedule and data collection procedure of the main study and to collect a coherent set of valuable data that offers the possibilities to examine at the same time the singularities of learners' trajectories, but also the communalities of learning and sociocultural experiences across individuals. Additionally, given the specificities and lack of research on the targeted population, our findings may help researchers who would like to collect qualitative data with comparable learner profiles anticipate similar difficulties when designing their research protocols.

\footnotetext{
${ }^{3}$ We would like to thank all the participants in this pilot study for sharing their stories and for their valuable contribution to the project.
} 
The SOFRA project sets out to longitudinally examine the relationships between the development of French as a L2 by Syrian refugees and asylum seekers ${ }^{4}$ enrolled in French language courses at a French university and the dynamics of their sociocultural adaptation in the host society. As such, it aims to contribute to reconsidering "disadvantaged" learners and to conducting "socially-relevant" SLA research to help these individuals face the considerable challenges related to SLA and therefore support their participation in the economic and social life of their new community (Young-Scholten, 2013).

In exploring links between the development of L2 acquisition and the social context, the project is informed by sociocultural theory. Having its origins in the writings of Vygotsky and his colleagues, sociocultural theory refers to human learning and developmental processes in general, and argues that learning generally happens "through participation in cultural, linguistic and historically formed settings" (Lantolf and Thorne, 2007, p. 197). When applied to SLA, the proponents of sociocultural theory argue that language acquisition does not take place only in the learner's mind but also in interaction with the social context (Lantolf, 2000; Ushioda, 2003; Lantolf and Thorne, 2007; Lantolf et al., 2015) and that SLA is in itself a social process

\footnotetext{
${ }^{4}$ The participants in the pilot study had both profiles: they were either refugees or asylum seekers. Given the limited number of participants and for anonymity purposes, this information is not provided when describing participants' profiles.
} 
in which learners are socially and culturally situated and engage in cultural activities mobilising cultural and semiotic tools (Tarone, 2007). .

The relationship between SLA and the social context has not always been taken into account in mainstream SLA research (cf. Véronique, 2013 for an overview). Using an integrated research perspective, where non-linguistic variables are considered on the same level as linguistic development, is all the more important for studying SLA in migration contexts given the special profile of learners, which has rarely received attention in SLA research (van Tubergen, 2010). More generally, there has been, in the last decades, a notable shift in interest from "disadvantaged" L2 learners and uneducated immigrant adults in naturalistic contexts (as in projects from the 70s and 80s, like the ESF Project ${ }^{5}$ (Perdue, 1993a, 1993b)) to focusing almost exclusively on educated, middle class learners (Young-Scholten, 2013). This resulted in a shift in SLA research scope and perspectives, as a number of "languageexternal factors" were left unaddressed (Young-Scholten, 2013: 441).

\footnotetext{
5 Researchers of the ESF project clearly acknowledged the weight of the sociocultural variables in understanding acquisition by immigrants. For example, attempts to correlate target language proficiency (ex. Lexical richness) and biographical information (age, family status) were made as shown in van Hout and Strömqvist (1993). Moreover, the researchers pointed to the impact of discrimination, cultural assumptions and power relations on SLA (Bremer et al., 1993). They have also noted the leaners' very limited communication opportunities in the target language, often limited to dealing with administrative matters, where they were particularly disadvantaged by their proficiency level in the target language and the asymmetrical power relations. Furthermore, they highlighted the paradoxical situation in which immigrants acquire a new language often in difficult sociocultural conditions: they need to communicate in order to learn and to learn in order to be able to communicate (Vion, 2000).
} 
Given the growing number of learners who develop linguistic skills in difficult psychological conditions (Mann and Fazil, 2006); and whose language acquisition is dependent on both their professional and social integration (Adami and André, 2015), there is a growing need for "socially relevant" SLA research that is capable of addressing non-linguistic variables that are decisive to language acquisition. Indeed, we share the concern of Véronique (2013: 270) that '[a]dult learners who may have suffered from social and psychological trauma due to the circumstances of their lives (economic migration, political asylum, etc.) cannot be sliced into neat components for the sake of elegant research'. The integrated approach adopted in this project aims to report on learning conditions, and learners' access to culturally meaningful practices within the target language community, including in the classroom (Norton and Toohey, 2011). The adoption of an integrated approach presents a set of methodological challenges as discussed in Hulstijn et al. (2014). In fact, establishing a causal link between data gathered through qualitative methods on social context and L2 development (investigated using predominantly quantitative methods) has been difficult to obtain. Furthermore, it presupposes intersecting approaches that have different orientations (Mackey, in Hulstijn et al. (2014)) and developing a methodology that speaks to different strands (Young, in Hulstijn et al. (2014); Firth and Wagner, 1997)). 
In this paper, we focus on the methodological considerations related to the collection of qualitative data gathered through interviewing in the SOFRA pilot study. In this exploratory phase, we set out to examine to what extent the non-linguistic variables that are identified in the literature and that we are interested in pertain to the researched population. Furthermore, we wanted to become familiar with the world in which the respondents live to acquire a better knowledge of the language they use and the interpretations they can give to the language we use during the interview.

\section{The pilot study}

\subsection{The targeted non-linguistic variables}

Given that language use is an important mediational tool (Vygotsky, 1986), and that language learning is a social practice (Lantolf et al., 2015) and a result of 'a relational engagement among participants of a community' (Miller and Kubota, 2013, p. 234); it is essential to examine how learners interact with people and artefacts from their new environment in order to understand language learning and development. In the pilot study, we set out to gather qualitative data on the following non-linguistic variables: (a) learners' access to and participation in culturally organised activities and communicative events, (b) learners' attitudes towards their new language and environment, and (c) learners' relationships with their country of origin and their first language (L1). 
Indeed, we intended to gather information on learners' opportunities for interaction in the target language as well as their exposure to input in French. Furthermore, by studying those aspects, we hoped to gain insights into learners' involvement in the host community and learn about the extent to which they have managed to develop 'insider identities' and legitimacy (Norton and Gao, 2008; Early and Norton, 2012; Norton, 2013). Moreover, focusing on how learners feel about their new environment and how they speak about the new culture and the people of the community they interact with is essential to understanding their learning experience, as well as their investment in learning the language and adaptation to the new context (Norton Peirce, 1995; Darvin and Norton, 2015). SLA research on attitudes has generally shown an interrelation between positive attitudes and the development of L2 proficiency (Gardner, 1985; Oroujlou and Vahedi, 2011; Zeinivand et al., 2015) and learners' disposition to learn (Ushioda and Dörnyei, 2017). Finally, we consider that information about the way in which individuals relate to their country of origin and L1 for this specific learner profile, given the similar conditions of forced migration that they have all undergone, may contribute to understanding how the participants adapt to their new environment.

\subsection{Testing an interview protocol}


In any type of research, the choice of data elicitation instruments is dependent on the type of data needed, hence on the research question asked as well as on the theoretical approach adopted (Mackey and Gass, 2005).

Research interested in understanding language development in relation to sociocultural context draws almost exclusively on qualitative data and narratives collected through qualitative methods, namely interviewing, diary writing or journaling (e.g. Norton, 2013; Pavlenko, 2001). In our project, we assume that in order to analyse SLA by Syrian asylum seekers and refugees based on a sociocultural approach, we need to understand how they relate to the community in which they are living and of which they wish to be part. Furthermore, following the work of Norton ( Norton, 2000; Norton and Toohey, 2011; Early and Norton, 2012; Norton, 2013), it is important in examining SLA to understand the world as the learners understand it. For those reasons, we rely on the learners' representations and understanding of their new environment, as expressed in their own discourse. The data elicitation instrument chosen for those purposes is therefore interviewing.

Interviewing is a widely-used technique in qualitative research, and there are different types of interviews that can be described on a continuum ranging from the fully structured to the completely unstructured (Bell, 2005; Mackey and Gass, 2005). Structured interviews are a rigid type of interview that are comparable to questionnaires, as the researcher sticks to a prepared set of questions, thus allowing to compare the participants' answers. Semi- 
structured interviews are based on an interview schedule or guide, but allow for digressions and more freedom of both the interviewer and the respondents. The last type is unstructured interviews, where the interviewer develops and adapts the questions to the respondents. Although no question list is used, the interviewer has to prepare a list of items $\mathrm{s} / \mathrm{he}$ needs to cover. While unstructured interviews can be more appropriate in preliminary studies, most studies using interviews rely on the semi-structured type, which both allows freedom to the respondents and ensures that the important topics are addressed (Bell, 2005).

Overall, given their interactive nature, interviews constitute a flexible tool that allows the researcher to adjust to the respondent and to elicit additional data in case there is need to clarify or to complete initial answers. Nevertheless, this data collection method can also have drawbacks. For instance, the researcher's subjectivity may interfere with the way the data are collected and interpreted. Moreover, participants may provide information that they believe is wanted or expected by the researcher, through what is termed 'the halo effect' (Mackey and Gass, 2005). Additionally, the questions asked may be inappropriate to certain cultural contexts. The interviewing process and the particularity of the conversation can be challenging for our respondents given that generally, 'the context of a linguistic encounter contains a tension - that between the uniqueness of a particular interaction 
and the shared constraints and principles of the society through which communication is mediated' (Bremer et al. 1993).

Finally, in order to elicit valuable data, the interviewer needs to develop good interviewing skills in order to face the different methodological challenges involved in conducting interviews: to know how to play with two very different language registers : the language of research that is used to codify reality and communicate the results to the scientific community, and the language used by respondents; to react in case of silence; and to guide the interview while letting the interviewee speak (Romelaer, 2005; Creswell, 2014).

The literature on research methods and data collection techniques offers a number of suggestions to help the researchers maximise their chances of gathering relevant rich data (e.g., Bell, 2005; Mackey and Gass, 2005). These include suggestions to build a positive and reassuring relationship between the interviewer and the interviewee, to prepare efficient questions that would elicit valuable data and to develop skills in anticipating and solving communication problems. However, as stated by Chaudron (2003, p. 773), '[s]urprisingly, in most of this literature, there is little description of exactly what sort of protocols, guidelines, questions, or procedures are employed'. Aware of the potential pitfalls involved in conducting interviews, as well as the added challenge of conducting them with Syrian asylum seekers and 
refugees who have predominantly low L2 proficiency skills, we planned to pilot test out data collection protocol as the first stage of the SOFRA project.

\section{Objectives, research questions and hypotheses of the pilot study}

Pilot testing consists of conducting 'small-scale trial of the proposed procedures, materials, and methods', with the aim of uncovering any problems, before testing and then finalising the materials and methods used in the main study (Mackey and Gass, 2005, p. 43). Pilot testing is therefore considered crucial in any type of research to avoid ending up with useless and non-valuable data.

We aim in this article to discuss the viability of the different methodological choices made for collecting data through semi-guided interviews. We focus on the nine participants' understanding of the questions asked during the semi-structured interviews, addressing in particular the following questions:

1) What are the questions that were difficult to understand by the respondents and what are those that elicited off-topic answers?

2) What are the interviewer's strategies when faced with different problems throughout the interviews?

We hypothesise, based on learners' L2 proficiency and the specificities of the language task (Perdue, 1993b), that problems of understanding of interviewer's questions would occur. Also, given the 
heterogeneity of questions types, it is expected that the relevance of interviewees' responses would vary depending on how the questions are structured and formulated. More precisely, negotiation for meaning and 'struggle to make meaning' (Perdue, 1993b: 254) would be more frequent with open-ended questions.

The article concludes with a discussion on how the pilot study helped inform the design of the interview schedule for the main data collection phase within the SOFRA project.

\section{Pilot study methodology}

\subsection{Participants}

The participants in the pilot study are nine Syrian adults, who have migrated to France, and who were enrolled in French language classes in the Department of FLE (Français Langue Etrangère) at a French university the year of data collection. All the learners came to France under the same conditions, benefiting from the assistance of the University of Toulouse. They share the same migration experiences and hosting conditions. Table 1 gives details about participants' profiles.

\begin{tabular}{|l|l|l|l|l|l|l|}
\hline Code & Sex & $\begin{array}{l}\text { Age } \\
\text { (years) }\end{array}$ & $\begin{array}{l}\text { Duration of } \\
\text { residence } \\
\text { (months) }\end{array}$ & Status & $\begin{array}{l}\text { Placement } \\
\text { test result }\end{array}$ & $\begin{array}{l}\text { L2 } \\
\text { proficiency }\end{array}$ \\
\hline
\end{tabular}

${ }^{6}$ The placement test is ELAO (http://www.elaotest.eu/edu/assmt) which allows to evaluate language proficiency using the Common European Framework of Reference (Council of Europe, 2001). 


\begin{tabular}{|l|l|l|l|l|l|l|}
\hline SY01 & Male & 19 & 32 & Single & A1 & Beginner \\
\hline SY02 & Female & 41 & 16 & $\begin{array}{l}\text { Married + } \\
\text { children }\end{array}$ & A1 & Beginner \\
\hline SY03 & Female & 19 & 35 & Single & A1 & Beginner \\
\hline SY04 & Male & 20 & 12 & Single & A1 & Beginner \\
\hline SY05 & Male & 20 & 12 & Single & A1 & Beginner \\
\hline SY06 & Male & 23 & 5 & Single & A2 & $\begin{array}{l}\text { Low } \\
\text { intermediat } \\
\text { e }\end{array}$ \\
\hline SY07 & Male & 28 & 35 & Single & B2 & $\begin{array}{l}\text { High } \\
\text { Intermediat } \\
\text { e }\end{array}$ \\
\hline SY08 & Female & 42 & 31 & $\begin{array}{l}\text { Married + } \\
\text { children }\end{array}$ & B1 & $\begin{array}{l}\text { High } \\
\text { intermediat } \\
\text { e }\end{array}$ \\
\hline SY09 & Male & 37 & 35 & $\begin{array}{l}\text { Married + } \\
\text { children }\end{array}$ & A1 & \begin{tabular}{l} 
Beginner \\
\hline
\end{tabular}
\end{tabular}

Table 1. Participants

Most of the informants had a beginner's level before they enrolled at the French department. The interviews were conducted six months after enrolment. However, the informants had only benefited from one month of instruction when they were interviewed. In fact, soon after they had started French courses, the students and personnel at the University of Toulouse went on strike. All teaching and pedagogical activities had to cease as the university was blocked and access to the campus was limited.

\subsection{General description of the dataset}

Table 2 describes the dataset in terms of duration of the recordings and corpus size (in the form of the number of turns and utterances).

\begin{tabular}{|l|r|r|r|}
\hline Participant & Duration & Turns & Utterances \\
\hline SY01 & $55^{\prime} 60^{\prime}$, & 228 & 343 \\
\hline SY02 & $54^{\prime} 56^{\prime}$, & 149 & 451 \\
\hline SY03 & $61^{\prime} 17^{\prime}$ & 391 & 660 \\
\hline
\end{tabular}




\begin{tabular}{|r|r|r|r|}
\hline SY04 & $43^{\prime} 22^{\prime \prime}$ & 145 & 487 \\
\hline SY05 & $41^{\prime} 10^{\prime}$ & 187 & 570 \\
\hline SY06 & $45^{\prime} 41^{\prime}$ & 164 & 456 \\
\hline SY07 & $50^{\prime} 20^{\prime}$ & 236 & 510 \\
\hline SY08 & $89^{\prime} 36^{\prime}$ & 325 & 819 \\
\hline SY09 & $71^{\prime}$ & 570 & 848 \\
\hline Mean & $57^{\prime} 35^{\prime}$, & 266.1 & 571.6 \\
\hline
\end{tabular}

Table 2. The data set

Overall, the interviews lasted less than an hour, and contained an average of 266 turns and 572 utterances.

\subsection{Data collection procedure}

Semi-structured interviews were conducted by the researcher (female, bilingual French/ Arabic) with each participant in person and were videorecorded. An interview schedule of 35 questions was used (see Appendix 1). The semi-structured type of interview was chosen to allow the respondent to talk about what was of central significance to them (Bell, 2005) and also to facilitate the interviewer moving easily from one topic to another, paying attention to the flow of the conversation and to the relevance of the respondents' answers.

We have chosen French as the language of the interviews in order to be able to conduct different types of analyses using software that is not possible to use for Arabic languages (e.g., lexicometric software), and also to analyse the learners' conversational abilities in the L2. Possibilities of translating the questions in Arabic or English were offered. Furthermore, all the documents presented to the participants, namely the participants' 
agreement and the presentation of the project's objectives, were trilingual (in French, Arabic and English). However, opportunities to switch to the L1 or to English were minimally taken and all the participants chose to hear and answer all questions in French. Some of the participants even reported that the interview was an opportunity for them to speak French and that similar opportunities were rare, especially at the time of the social movement, where access to the university was impossible.

\subsection{Interview schedule}

The interview schedule contained 35 questions (Appendix 1). Among other things, these questions elicited information about (a) learners' access to French language and culture and interaction opportunities in the target language; (b) their attitudes towards the new language, their learning experience and new environment as well as their (c) relationship to their culture. We focus, in this paper, on only the 19 questions which targeted those three topics (see Table 3). The category (b) was divided into two subcategories: attitudes towards the new culture and environment and attitudes/comments about learning experience.

\begin{tabular}{|l|l|l|l|}
\hline Variables & $\begin{array}{l}\text { Targeted } \\
\text { information }\end{array}$ & Prepared questions & Question type \\
\hline \multirow{5}{*}{} & French friends & $\begin{array}{l}\text { Avez-vous des amis ? sont-ils } \\
\text { français? }\end{array}$ & $\begin{array}{l}\text { Closed- } \\
\text { ended/Double }\end{array}$ \\
\cline { 2 - 4 } & L2 practice & $\begin{array}{l}\text { Au quotidien, à quelle fréquence } \\
\text { parlez-vous français et avec qui? }\end{array}$ & $\begin{array}{l}\text { Closed- } \\
\text { ended/Double }\end{array}$ \\
\cline { 2 - 4 } $\begin{array}{l}\text { Access } \\
\text { and } \\
\text { interactio }\end{array}$ & $\begin{array}{l}\text { Quality of } \\
\text { interactions in }\end{array}$ & $\begin{array}{l}\text { Comment se passent vos } \\
\text { interactions avec les Français? }\end{array}$ & Open-ended \\
\hline
\end{tabular}




\begin{tabular}{|c|c|c|c|}
\hline \multirow[t]{2}{*}{$\begin{array}{l}\text { n } \\
\text { opportuni } \\
\text { ties in } \\
\text { French }\end{array}$} & $\begin{array}{l}\text { Anecdotes } \\
\text { about L2 use }\end{array}$ & $\begin{array}{l}\text { Quelles expériences positives et } \\
\text { négatives vous marquent en lien } \\
\text { avec votre utilisation du } \\
\text { français? Racontez des anecdotes } \\
\text { qui vous ont fait rire ou au } \\
\text { contraire énervé en lien avec } \\
\text { votre utilisation du français. }\end{array}$ & $\begin{array}{l}\text { Open-ended } \\
\text { /Double }\end{array}$ \\
\hline & $\begin{array}{l}\text { Exposure to } \\
\text { L2 in media }\end{array}$ & $\begin{array}{l}\text { Lorsque vous écoutez la radio ou } \\
\text { allumez la télévision, mettez-vous } \\
\text { des ondes/chaînes arabes ou } \\
\text { françaises? Lesquelles? }\end{array}$ & $\begin{array}{l}\text { Closed-ended } \\
\text { /Double }\end{array}$ \\
\hline \multirow{6}{*}{$\begin{array}{l}\text { Attitudes } \\
\text { towards } \\
\text { the new } \\
\text { environm } \\
\text { ent }\end{array}$} & $\begin{array}{l}\text { Attitudes } \\
\text { towards } \\
\text { France }\end{array}$ & $\begin{array}{l}\text { Qu'est-ce qui vous plaît/déplaît en } \\
\text { France? }\end{array}$ & $\begin{array}{l}\text { Open- } \\
\text { ended/Double }\end{array}$ \\
\hline & $\begin{array}{l}\text { Attitudes } \\
\text { towards L2 } \\
\text { culture }\end{array}$ & $\begin{array}{l}\text { Comment voyez-vous la culture } \\
\text { française? Donnez } 3 \text { choses qui } \\
\text { la symbolisent (ex. personnalités, } \\
\text { monuments, livres, écrivains...) }\end{array}$ & $\begin{array}{l}\text { Open- } \\
\text { ended/Double }\end{array}$ \\
\hline & $\begin{array}{l}\text { Representation } \\
\text { s of France }\end{array}$ & $\begin{array}{l}\text { Que représente pour vous la } \\
\text { France? }\end{array}$ & Open-ended \\
\hline & $\begin{array}{l}\text { Attitudes } \\
\text { towards the } \\
\text { French }\end{array}$ & $\begin{array}{l}\text { Comment voyez-vous les } \\
\text { Français? }\end{array}$ & Open-ended \\
\hline & $\begin{array}{l}\text { Sensitivity to } \\
\text { L1/L2 Cultural } \\
\text { differences }\end{array}$ & $\begin{array}{l}\text { Quelles sont les différences entre } \\
\text { la culture française et la vôtre? }\end{array}$ & Open-ended \\
\hline & $\begin{array}{l}\text { Feelings in the } \\
\text { L2 } \\
\text { environment }\end{array}$ & $\begin{array}{l}\text { Comment vous sentez-vous depuis } \\
\text { que vous êtes en France? }\end{array}$ & Open-ended \\
\hline \multirow{6}{*}{$\begin{array}{l}\text { Attitudes } \\
\text { towards } \\
\text { learning } \\
\text { experienc } \\
\text { e }\end{array}$} & $\begin{array}{l}\text { Attitudes } \\
\text { towards L2 } \\
\text { learning }\end{array}$ & $\begin{array}{l}\text { Est-ce que c'est plus ou moins } \\
\text { difficile pour vous d'apprendre le } \\
\text { français par rapport aux autres } \\
\text { langues que vous avez apprises? } \\
\text { si oui, pourquoi? }\end{array}$ & $\begin{array}{l}\text { Closed- } \\
\text { ended/Double }\end{array}$ \\
\hline & $\begin{array}{l}\text { Self evaluation } \\
\text { in L2 }\end{array}$ & $\begin{array}{l}\text { Quel niveau de langue pensez- } \\
\text { vous avoir actuellement? }\end{array}$ & Closed-ended \\
\hline & L2 Motivation & $\begin{array}{l}\text { Qu'est-ce que l'apprentissage du } \\
\text { français pourrait vous apporter? }\end{array}$ & Open-ended \\
\hline & $\begin{array}{l}\text { Investment in } \\
\text { L2 }\end{array}$ & $\begin{array}{l}\text { A quelle fréquence travaillez- } \\
\text { vous? où? (Demander des } \\
\text { détails en fonction de la réponse) }\end{array}$ & $\begin{array}{l}\text { Closed- } \\
\text { ended/Double }\end{array}$ \\
\hline & $\begin{array}{l}\text { Reflections on } \\
\text { the instructed } \\
\text { L2 }\end{array}$ & $\begin{array}{l}\text { Le français que vous étudiez au } \\
\text { Defle est-il différent de ce que } \\
\text { vous entendez à l'extérieur? }\end{array}$ & Closed-ended \\
\hline & $\begin{array}{l}\text { Reflection on } \\
\text { evaluations }\end{array}$ & $\begin{array}{l}\text { Comment se sont passés vos } \\
\text { examens? étiez-vous assez } \\
\text { préparé? }\end{array}$ & $\begin{array}{l}\text { Open- } \\
\text { ended/Double }\end{array}$ \\
\hline
\end{tabular}




\begin{tabular}{|l|l|l|l|}
\hline $\begin{array}{l}\text { Relations } \\
\text { hips to } \\
\text { their own } \\
\text { country } \\
\text { and } \\
\text { culture }\end{array}$ & $\begin{array}{l}\text { Contact with } \\
\text { country of } \\
\text { origin }\end{array}$ & $\begin{array}{l}\text { Ettach-vous en contact avec vos } \\
\text { proches de votre pays d'origine? } \\
\text { Par quels moyens? }\end{array}$ & $\begin{array}{l}\text { Closed- } \\
\text { ended/Double }\end{array}$ \\
\cline { 2 - 4 } & $1^{\text {st }}$ culture & $\begin{array}{l}\text { Y-a-t-il des éléments de votre } \\
\text { culture que vous souhaiteriez } \\
\text { conserver ? Pourquoi? }\end{array}$ & $\begin{array}{l}\text { Open- } \\
\text { ended/Double }\end{array}$ \\
\hline
\end{tabular}

Table 3. Questions used in the data subset

Furthermore, in order to easily refer to the listed questions throughout the analyses, each one of them was summarised in the column Targeted information. Finally, a description of each question type is provided in the last column, in terms of complexity (simple or double) and in terms of type of answer required (open-ended or closed-ended). Simple questions focus on only one aspect of the topic addressed. Double questions, however, target two different pieces of information. They are written using two question marks in the interview schedule (Table 3). Four categories of prepared questions were distinguished Open-ended ( $n=5)$; Closed-ended $(n=2)$; Open-ended/Double $(n=6)$ and Closed-ended/Double $(n=6)$. These question categories will be used in the analysis of the interviews.

\subsection{Data transcription, coding and analysis}

The interviews were entirely transcribed in CHAT format using the software CLAN (MacWhinney, 2000). The transcriptions were overall orthographic, except for words and chunks that did not correspond to what would be expected in the context of the utterance. These were transcribed phonetically and coded using CHAT conventions. In the examples provided in this article,@u is affixed to such instances. 
Respondents' turns were divided into utterances to have comparable data units across interviews. An utterance is the smallest meaningful speech unit. Most learner utterances are organised around a finite verb, although some are structured with a non-finite verb form/base form or even without a verb (Klein and Perdue, 1992).

The dataset based on the 19 questions listed in Table 3 was divided into subparts. For each interview, 19 data files were created, each of which contained the turns used to respond to one of the nineteen questions. The dataset analysed in the current article thus corresponds to a total of $171 \mathrm{CHAT}$ files.

As a reminder, our objective in interview piloting was to test the interview protocol to ensure that interviews conducted in the main study will allow us to gather coherent, complete, valuable and comparable data across all participants. In order to achieve that, each of the planned questions should be easily understood by each participant and should spontaneously elicit ontopic answers. Furthermore, risks of bias and data variation are two major concerns and have to be avoided. Therefore, we examined how the interviewer actually asked each question and how the interviewee responded. The aim is to assess if the question was clear enough and adapted to the participant's profile and to examine, in case of difficulties, the interviewer's reactions and attempts to clarify the question and obtain the most relevant answer possible. Indeed, we elaborated a bottom-up coding scheme to analyse 
conversations in the different files in terms of the apparent clarity of the questions from the respondents' perspectives and the relevance of answers from the point of view of the interviewer (whether they were on-topic or offtopic). Parts of conversations that did not directly relate to the pre-set list of questions were coded as digressions. Table 4 presents the information coded in the interviewer's and the respondents' speech.

\begin{tabular}{|l|l|l|}
\hline \multirow{4}{*}{$\begin{array}{l}\text { Coding } \\
\text { respondents, } \\
\text { turns }\end{array}$} & $\begin{array}{l}\text { Codes } \\
\text { Direct on-topic } \\
\text { answers }\end{array}$ & $\begin{array}{l}\text { Interpretation } \\
\text { On-topic answers provided immediately } \\
\text { after the question was asked. }\end{array}$ \\
\cline { 2 - 3 } & QQ & $\begin{array}{l}\text { Responses that did not answer the } \\
\text { question asked. }\end{array}$ \\
\cline { 2 - 3 } & $=\mathrm{Q}$ & $\begin{array}{l}\text { Questions asked as a reaction to the } \\
\text { interviewer's question. }\end{array}$ \\
\cline { 2 - 3 } & \#Q & Requests to repeat the question \\
\cline { 2 - 3 } Coding & Digressions & Signalling that the question was unclear \\
\hline \multirow{5}{*}{ turns } & RefQ & $\begin{array}{l}\text { Departures from the main topic } \\
\text { addressed by the question. }\end{array}$ \\
\cline { 2 - 3 } & RepQ & Question reformulation \\
\cline { 2 - 3 } & TransQ & Question repetition \\
\cline { 2 - 3 } & RepTransQ & $\begin{array}{l}\text { Question translation into Arabic or } \\
\text { English }\end{array}$ \\
\cline { 2 - 3 } & ClaQ & $\begin{array}{l}\text { Repetition of question translations } \\
\text { Clarification questions asked following } \\
\text { respondents' answers }\end{array}$ \\
\cline { 2 - 3 } & RefA & $\begin{array}{l}\text { Reformulation of respondents' } \\
\text { utterances }\end{array}$ \\
\cline { 2 - 3 } & SuggA & $\begin{array}{l}\text { Utterances giving examples of possible } \\
\text { answers }\end{array}$ \\
\cline { 2 - 3 } & Further questions \\
\cline { 2 - 3 } & FurtherQ & $\begin{array}{l}\text { Departures from the main topic } \\
\text { addressed by the question. }\end{array}$ \\
\cline { 2 - 3 } & Digressions* &
\end{tabular}

Table 4. Coding of interviews

*The interviewer's digressions will not be addressed in the analysis.

\section{Results}




\subsection{Clarity and reception of the questions from the point of view}

\section{of the respondents}

One of the most important characteristics of a good interview is that it is constructed using questions that are clear enough to yield the best and most relevant responses. Therefore, we wanted in this pilot study to check the validity and clarity of the questions asked during the interviews, in particular examining how the different respondents reacted to each one of them. We therefore reflected on whether the prepared set of questions was really adapted to the respondents, looking at instances where they were apparently unclear, ambiguous and needed explanations and reformulations by the interviewer. Table 5 summarises the reactions of the respondents to the different questions asked. These reactions are classified in terms of whether the respondents gave:

(a) on-topic and direct responses to the interviewer's question (Direct on-topic responses);

(b) on-topic responses given after seeking further clarifications, a category which was further subdivided into asking questions in their own words (QQ), asking the researcher to repeat the question $(=Q)$, or saying that the question was unclear and that they did not understand it (\#Q); and finally

(c) off-topic responses; which revealed that the question was misunderstood 


\begin{tabular}{|l|l|l|l|l|l|}
\hline & \multirow{2}{*}{$\begin{array}{l}\text { Direct } \\
\text { on-topic }\end{array}$} & \multirow{2}{*}{$\begin{array}{l}\text { Off-topic } \\
\text { Interview schedule / Questions }\end{array}$} & \multicolumn{3}{|l|}{ Clarification requests } \\
\cline { 5 - 7 } & responses & RQ & Q & Q & \#Q \\
\hline Investment in L2 & 7 & 1 & 1 & 0 & 2 \\
\hline French friends & 8 & 0 & 1 & 0 & 0 \\
\hline Contact with country of origin & 7 & 0 & 2 & 1 & 0 \\
\hline Attitudes towards L2 & 6 & 1 & 1 & 0 & 0 \\
\hline Reflections on the instructed L2 & 7 & 0 & 3 & 0 & 0 \\
\hline Reflexions on Evaluations & 5 & 1 & 1 & 0 & 2 \\
\hline Quality of interactions in L2 & 5 & 3 & 0 & 0 & 1 \\
\hline Representations of France & 6 & 3 & 0 & 1 & 0 \\
\hline Attitudes towards the French & 5 & 3 & 1 & 0 & 0 \\
\hline Feelings in the L2 environment & 6 & 0 & 2 & 0 & 0 \\
\hline L2 motivation & 5 & 0 & 2 & 2 & 1 \\
\hline L2 Practice & 6 & 0 & 3 & 0 & 0 \\
\hline Exposure to L2 in media & 5 & 2 & 3 & 0 & 1 \\
\hline Attitudes towards France & 6 & 0 & 4 & 1 & 1 \\
\hline Anecdotes about L2 use & 4 & 5 & 4 & 1 & 3 \\
\hline Self-evaluation in L2 & 4 & 0 & 6 & 1 & 0 \\
\hline Attitudes towards L2 culture & 3 & 5 & 0 & 0 & 3 \\
\hline $\begin{array}{l}\text { Sensitivity to L1/L2 cultural } \\
\text { differences }\end{array}$ & 4 & 2 & 5 & 0 & 0 \\
\hline Attachment to L1 culture & 2 & 3 & 8 & 1 & 5 \\
\hline Average (\% out of 9 participants) & 59.1 & 17 & 27.5 & 4.7 & 11.1 \\
\hline Sd deviation & 16.6 & 19 & 24.1 & 6.7 & 15.7 \\
\hline
\end{tabular}

Table 5. Respondents' reactions to questions

Overall, on average, only about $59 \%$ of all responses were on-topic and provided immediately after hearing the question. About $23 \%$ (nearly $1 / 4$ of the questions) of all responses were given following clarifications requests. The remaining $17 \%$ of the answers provided were off-topic. The high standard deviation (15.4\%) of average relevant answers reveals large discrepancies across questions. As Figure 1 shows, these differences can be interpreted in relation to the types of questions asked: 


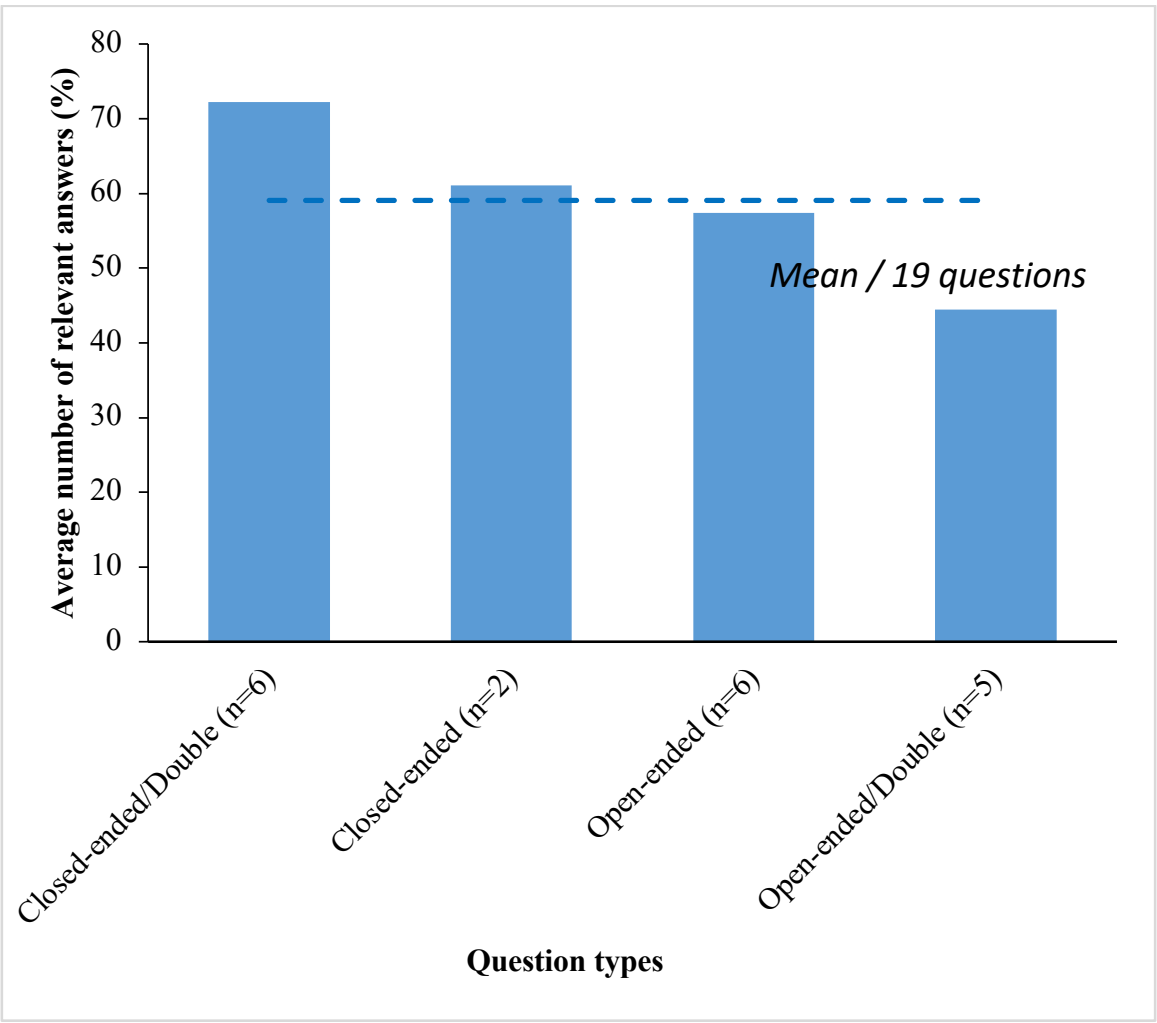

Figure 1. Distribution of average number of on-topic answers per question type

Closed-ended questions are those that yield relevant answers more often than open-ended questions. For our interview type, closed-ended questions were meant as triggers to address certain topics. For example, the question Avez-vous des amis? Sont-ils français? was meant to yield information about the respondents' social life and give elements about their involvement with the target language community. However, when the respondent's answer was limited to "oui j'ai des amis et ils sont français", the answer is considered as relevant even though it is unsatisfactory to the interviewer. Furthermore, closed-ended (simple or double) questions were generally formulated using words that are available in the respondents' input 
(e.g., amis, parler français, contact, pays d'origine, niveau de langue). Consequently, clarification requests were rare with this question type. Conversely, open-ended questions were longer and contained unknown words. Indeed, some turned out to be confusing and difficult to understand, due to unsuitable vocabulary (e.g., éléments, conserver), which explains the numerous clarification requests formulated by the respondents. The example in (1) shows a clarification request to the question 'Attachment to L1 culture', which was particularly challenging for the respondents.

\section{1) SY03, Attachement to L1 culture}

*SY03: conserver ça veut dire?

*INT: garder.

*SY03: garder?

*SY03: ah garder.

In addition, questions addressing topics related to the present were those that were more likely to be easily understood by the participants (e.g., 'Attitudes towards the new environment', 'Attitudes towards L2 learning'). Conversely, those which were related to the past (e.g., 'Attachment to L1 culture'), or made links between the past and the present seemed to require more clarifications. Additionally, nearly all the questions related to cultural/intercultural sensitivity were less likely to receive relevant answers (see Figure 2). 


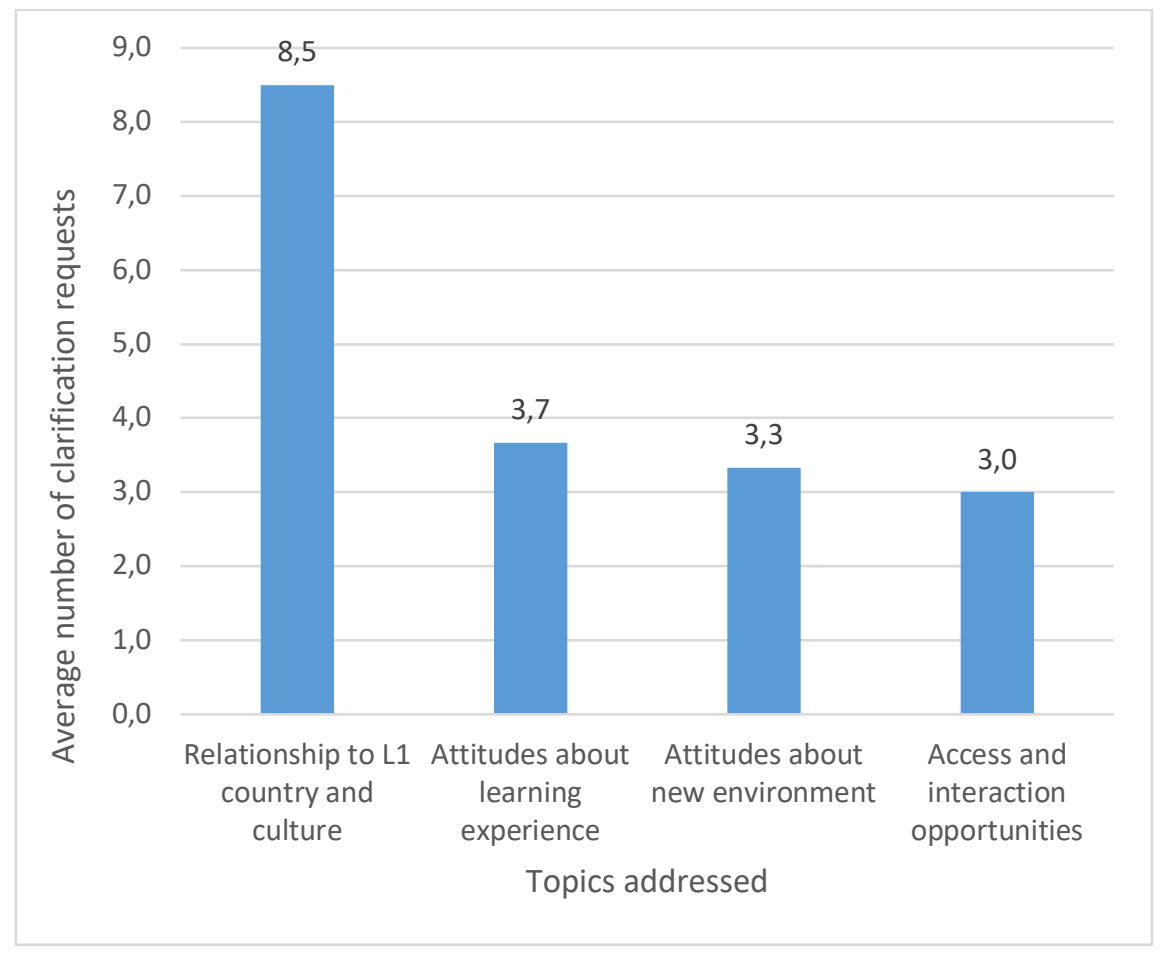

Figure 2. Average number of clarification requests in terms of the topics addressed Furthermore, most of the off-topic answers occur with the questions 'Anecdotes about L2 use' and 'Attitudes towards L2 culture'. These are the lengthiest and most complex of all the questions. They were also those that were the most frequently reformulated, repeated and explained. Question wording can explain why these two questions were particularly problematic. In fact, clarification requests concerning the words anecdote and énervé were frequent and clarification attempts were sometimes unsuccessful as in (2).

2) SY09, Anedotes about L2 use

*SY09: énervé c'est?

*INT: énervé c'est fâché .

*SY09: fâché ?

*INT: \&-ah je vais vous dire la traduction. Angry .

*SY09: ah angry? 
Moreover, we examined cases where the respondents digressed from the topics addressed by the questions. Digressions are participants' utterance(s) that were not produced as an answer to the question and that had no direct relationship with the question asked. Digressions are not to be confused with off-topic answers, where the respondents clearly fail to understand the question despite the interviewer's reformulation and clarification attempts. They are of importance in our investigation because they can help us see what is of particular importance to the learners. Furthermore, they help to understand whether in the list of prepared questions there are redundant questions. Table 6 presents frequencies of respondents' digressions. These are not very frequent in the interviews.

\begin{tabular}{|l|l|}
\hline \multicolumn{2}{|l|}{} \\
Number of digressions per question \\
\hline Representations of France & 5 \\
\hline Exposure to L2 in media & 2 \\
\hline Self-evaluation in L2 & 2 \\
\hline Feelings in the L2 environment & 2 \\
\hline Attitudes towards France & 2 \\
\hline Attachment to L1 culture & 2 \\
\hline L2 Practice & 1 \\
\hline Quality of interactions in L2 & 1 \\
\hline L2 investment & 1 \\
\hline Attitudes towards the French & 1 \\
\hline $\begin{array}{l}\text { Sensitivity to L1/L2 cultural } \\
\text { differences }\end{array}$ & 1 \\
\hline Attitudes towards L2 culture & 1 \\
\hline French friends & 0 \\
\hline Anecdotes about L2 use & 0 \\
\hline Attitudes towards L2 & 0 \\
\hline Reflections on evaluations & 0 \\
\hline
\end{tabular}

\begin{tabular}{|l|l|l|}
\hline & $\begin{array}{l}\text { L2 } \\
\text { Proficiency }\end{array}$ & $\begin{array}{l}\text { Number of } \\
\text { digressions } \\
\text { per } \\
\text { respondent }\end{array}$ \\
\hline S01 & A1 & 0 \\
\hline S02 & A1 & 2 \\
\hline S03 & A1 & 2 \\
\hline S04 & A1 & 1 \\
\hline S05 & A1 & 3 \\
\hline S06 & A2 & 3 \\
\hline S07 & B2 & 0 \\
\hline S08 & B1 & 6 \\
\hline S09 & A1 & 4 \\
\hline
\end{tabular}




\begin{tabular}{|l|l|}
\hline L2 motivation & 0 \\
\hline Reflections on instructed L2 & 0 \\
\hline
\end{tabular}

Table 6. Respondents' digressions

Digressions do not occur with all the interview questions. Indeed, six out of the 19 questions were answered by all the participants without departing from the main topic. Overall, respondents' digressions are very limited, which could be interpreted in relation to the low L2 proficiency of most of the respondents. In (3), SY09 deviates from the question about his representation of the host country to talk about why he likes the French language.

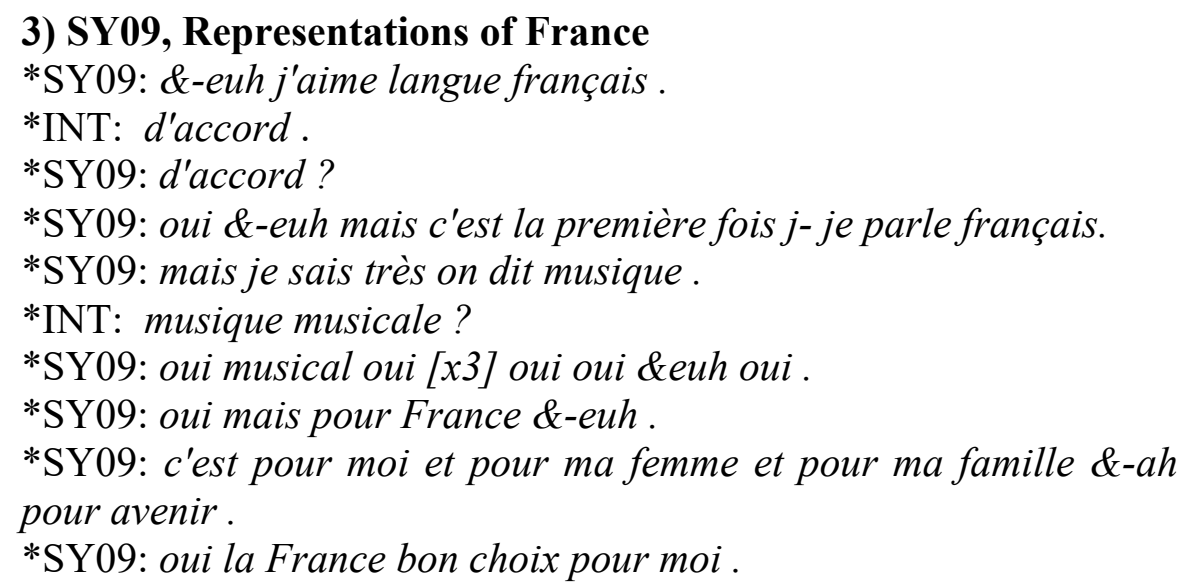

It is hypothesised here that the digression may stem from an ambiguity related to the word "France" and possibly the proximity with the words le français and langue *français. The respondent manages on his own to adjust to the question asked and provide a more appropriate answer: oui mais pour France.... 
Similarly, (4), SY02 answers the question and departs from the topic to make comparisons between France and Syria. Clearly, the question about 'Representations of France' can possibly elicit information about cultural differences between the country of origin and the new environment. This information is also yielded by the question 'Sensitivity to L1/L2 cultural differences'.

\footnotetext{
4) SY02, Representations of France

*SY02: je pen- en france je pense la connaissance avec les gens ça le le le première chose.

*SY02: maismais sionsijeps@uze@upasmerit@uce poste.

*SY02: je peux pas euh le le zobtenir@u comme euh en syrie .

*SY02: en Syrie euh (.) si euh mon niveau des études en haut et l'autre le bas .

*SY02: il va obtenir ce poste .

*SY2: je pense en france iz̃̃@u respekt@u respekt@uleniveaudes études mais les connaissances.
}

\subsection{Clarity and reception of the questions from the point of view}

\section{of the interviewer}

\subsubsection{Interviewer's clarification attempts}

As a reminder, we analysed the way in which the questions were asked by the interviewer in order to examine their formulation across interviews as well as the strategies used to cope with comprehension problems. In particular, we looked at cases where she had to reformulate (RefQ), repeat (RepQ), translate them once (TransQ) or twice (Rep TransQ). Table 7 gives details about the frequencies of each type per question (all respondents). 
Additionally, the table presents in the last column the total number of respondents' clarification requests per question (presented above in Table 5).

\begin{tabular}{|l|l|l|l|l|l|}
\hline Questions & RefQ & RepQ & TransQ & $\begin{array}{l}\text { Rep } \\
\text { TransQ }\end{array}$ & $\begin{array}{l}\text { Total } \\
\text { clarification } \\
\text { requests }\end{array}$ \\
\hline Anecdotes about L2 use & 14 & 2 & 2 & 1 & 8 \\
\hline Quality of interactions in L2 & 12 & 2 & 0 & 0 & 3 \\
\hline Attachment to 1st culture & 12 & 2 & 1 & 0 & 14 \\
\hline L2 Investment & 11 & 4 & 1 & 0 & 3 \\
\hline Feelings in the L2 environment & 10 & 2 & 1 & 1 & 1 \\
\hline Reflexions on instructed L2 & 10 & 1 & 0 & 0 & 3 \\
\hline Attitudes towards France & 8 & 9 & 1 & 1 & 6 \\
\hline L2 Practice & 8 & 0 & 0 & 0 & 2 \\
\hline Attitudes towards the French & 7 & 5 & 0 & 0 & 1 \\
\hline Representations of France & 7 & 4 & 1 & 0 & 4 \\
\hline $\begin{array}{l}\text { Sensitivity to L1/L2 cultural } \\
\text { differences }\end{array}$ & 7 & 3 & 0 & 0 & 5 \\
\hline Attitudes towards L2 culture & 5 & 4 & 2 & 1 & 3 \\
\hline Reflections on evaluations & 5 & 3 & 0 & 0 & 3 \\
\hline L2 motivation & 4 & 3 & 0 & 0 & 5 \\
\hline Self Evaluation in L2 & 3 & 1 & 1 & 0 & 7 \\
\hline Exposure to L2 in media & 2 & 2 & 1 & 0 & 1 \\
\hline Attitudes towards L2 learning & 2 & 1 & 0 & 0 & 1 \\
\hline Contact with country of origin & 1 & 6 & 0 & 0 & 3 \\
\hline French Friends & 0 & 1 & 0 & 0 & 1 \\
\hline Total & 128 & 55 & 11 & 4 & 74 \\
\hline
\end{tabular}

Table 7. Analysis of interviewer's questions

First of all, the interviewer very rarely had recourse to translation to further clarify the questions (11 translations and 4 translation repetitions in the dataset). As a matter of fact, the participants never asked the interviewer to translate the question into another language (L1 or English) even though they knew that it was possible. The interviewer had recourse to translation when reformulations were not efficient (as in [2] above). The interviewer reformulated the questions when needed (128 reformulations). However, 
frequencies of the respondents' clarification requests presented in the last column of Table 7 suggest that the questions that are most frequently reformulated are not necessarily those for which the participants asked for clarifications. Additionally, the researcher, overall, provides more clarifications than requested.

Indeed, only some of the interviewer's repetitions, reformulations, and translations were induced by the respondents' explicit clarification requests. She also produced self-initiated repairs and reformulated in multiple manners when she saw that the respondent did not understand the question as in (5), where the interviewer reformulates the question many times preceding the respondent's overt clarification requests.

\section{5) SY06, Attitudes towards L2 culture}

*INT: euh d'accord comment vous voyez la culture française?

*INT: est-ce que vous pouvez donner des choses qui la symbolisent.

*INT : qu'est-ce qui symbolise pour vous la culture française et qui la rend différente?

*SY07: sais pas non .

*INT: si vous pouvez penser à des personnalités par exemple ou des monuments ou des écrivains des choses des événements .

*SY07: j(e) (n)'ai pas compris la question .

The interviewer's reformulations were either explicitly requested or induced by implicit indications from the respondents that the question was not understood, either through nonverbal behaviour, gesture, facial expression, or as a result of a lengthened reaction time etc. Respondents' difficulties can be interpreted with relation to their linguistic abilities in the L2, but also attributed to the wording of questions. In fact, many of 
interviewer's reformulations are produced immediately after asking the question, and repeatedly for the same questions with many participants. For instance, the question about the 'Quality of interactions in L2' (worded as follows in the interview schedule: Comment se passent vos interactions avec les Français?) is frequently followed by reformulations. In addition, it is differently worded with each respondent. Indeed, in (6) the interviewer introduces in the question's reformulation an element - comment vous vivez l'expérience? - which reorients the conversation from speaking about factual information concerning L2 interactions to focusing on the respondents' feelings about the experience, resulting in the use of adjectives such as (facile , pas difficile) in the respondent's answers.

\author{
6) SY02, Quality of interactions in L2 \\ *INT: et quand vous parlez avec des français alors comment ça se \\ passe? \\ *INT: comment vous vivez l'expérience? \\ *SY02: pas très facile (.) non non non . \\ *SY02: pas facile et pas beaucoup difficile au même temps .
}

Furthermore, the interviewer sometimes gives examples to help the respondent understand the question. In (7), while reformulating, she also provided suggestions of possible and somehow expected answers. These suggestions clearly influenced the way the respondent answered

\title{
7) SY06, Quality of interactions in $\mathbf{L 2}$
}

*INT: quand vous parlez avec des français comment ça se passe comment les interactions comment elles se passent pour vous ?

*INT: est-ce qu'il y a des choses qui vous marquent particulièrement sur ces échanges par rapport à votre utilisation du français? 
*INT: c'est-à-dire est-ce que par exemple quand vous parlez avec des français vous vous sentez bloqué ou euh les interactions se passent très bien parce que on est bienveillant surtout à ces moments où vous n'étiez pas très à l'aise avec votre utilisation. *SY07: euh avant vous voulez dire ?

*INT: oui enfin si vous pouvez parler de \&-euh .

*SY07: avant j'avais j'avais peur de parler.

\subsubsection{Interviewer's reactions to responses}

Interviewer's turns in a semi-structured interview can serve different purposes: to signal to the interviewee that s/he can continue talking by saying 'oui', for example; to summarise what has just been said, to ask for more clarifications and depth, to refocus the conversation when the respondent departs from the topic addressed or to ask further questions that are not planned in the interview schedule (Romelaer, 2005). We examined the way the interviewer reacted to the different types of responses provided by the participants. These reactions were reformulations (RefA) to clarify the content of what has been said or to rephrase what the respondent is struggling to say using more "understandable" words, as in (8).

8) SY09, Sensitivity to L1/L2 cultural differences

*SY09: parce que moi je considr-considérais la langue est a lieu [*] à la culture .

*SY09: beaucoup mais parce que la langue EvolyE@u jour par jour

*INT: elle évolue oui [/] oui .

*SY09: oui .

*INT: ça change tous les jours .

The interviewer also asked clarification questions about what was said $(\mathrm{ClaQ})$ in order to clarify the content of the respondent's speech as in (9). 


\section{9) SY02, Feelings about France}

*SY02: je peux encore euh (.) parler.

*SY02: je peuxdi@u ditcl@u?

*INT: discuter?

*SY02: discuter avec autres .

*SY02: il n'y a pas le le s- sentir?

*INT: le sentiment?

*SY02: le sentiment d'être isolé .

Lastly, the interviewer suggested possible answers (SuggA). Even though these suggestions were generally produced as a reaction to off-topic answers, and were therefore meant to further clarify the content of the question asked, they can be considered as instances of bias that affect the respondents' answers.

The distribution of all reactions per question types is presented in Figure 3. Open-ended questions are those which were more frequently followed up by unclear answers which required reformulations and clarifying questions by the interviewer. SuggA were more often produced with openended/double questions like 'Anecdotes about L2 use', 'Attitudes towards L2 culture' or 'Attachment to 1st culture', which further suggests that those questions need to be reconsidered, and reworded to suit our respondents' L2 skills. 


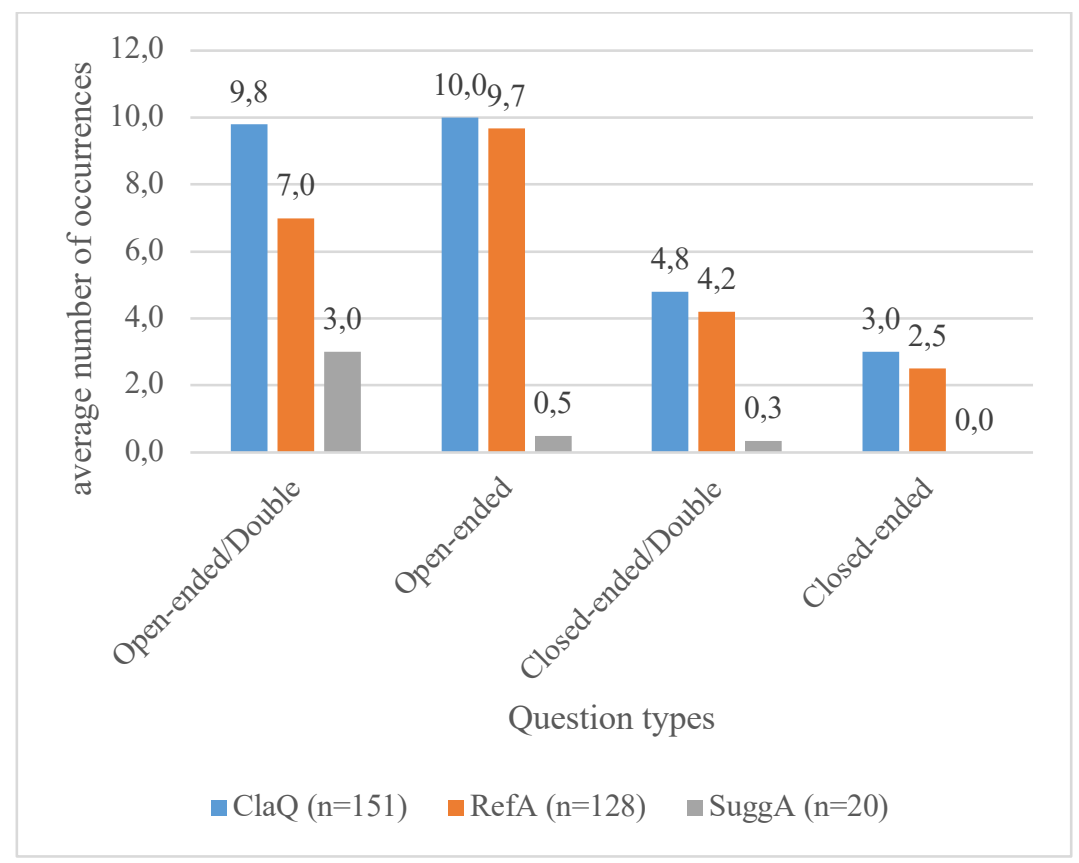

Figure 3. Interviewer's reactions to respondents' answers

\section{Discussion of results}

Our findings confirm that pilot testing is crucial (Mackey and Gass, 2005). It revealed a number of promising findings: Firstly, nearly all the participants who were solicited were willing to participate in the study and considered it as an opportunity to practice their French. In fact, they were all willing to answer the questions in their L2, and their answers show that despite the linguistic difficulties that were at times felt, the participants' attitudes remained very positive throughout the interviews.

However, pilot testing also revealed that despite being prepared to conduct the interviews, and the care with which we had prepared the 
interview schedule, we had not always achieved our goals. These goals are also shared by researchers who would like to gather qualitative data through interviewing, as argued by Bell (2005, p. 14):

[w] hichever method of information gathering is selected, the aim is to obtain answers to the same questions from a large number of individuals to enable the researcher not only to describe but also to compare, to relate one characteristic to another and to demonstrate that certain features exist in certain categories.

We failed to obtain on-topic answers to all the prepared questions: some answers were irrelevant as they were off-topic, others were redundant, and overall, comprehension problems were recurrent. Interviewers' reformulations, self-initiated repairs and clarification strategies were not well anticipated, and therefore, they were not systematic.

In fact, despite the wealth of information and richness of the data collected, the multiple clarification requests explicitly formulated by the participants as well as the need felt by the interviewer to rephrase, repeat and clarify the questions has revealed a number of methodological problems. These have to be solved in order to reach our goals in the main study: to maximize the coherence of the data and to be able to examine the uniqueness of learners' experiences and at the same time the communalities of learning and sociocultural experiences across individuals.

To sum up, a number of methodological pitfalls could be avoided thanks to pilot testing. These concern (a) interview schedule and question 
wording, (b) interview conducting and problem-solving strategies, and (c) adaptability of the data collection type and procedure to the targeted population.

\section{(i) Interview schedule and question wording}

The most outstanding result is that many aspects of the interview schedule and question wording needed to be entirely reviewed for the main study, given all the observed difficulties to access meaning and respond to the questions asked.

First, interviewees' responses and digressions have shown that many different questions in the interview schedule elicited similar content. For example, the three questions on 'Attitudes about L2 culture', 'Attitudes about France' and 'Sensitivity to L1/L2 cultural differences' frequently yielded comparisons of L1 and L2 environments by many respondents. Being actively engaged in adapting to a new environment, acquiring a L2 culture and restructuring their conceptual system (Lantolf, 1999), it seems natural that attitudes towards that new environment may be expressed through comparisons with the well-known environment. It is obvious that the three questions need to be rephrased, simplified, and refocused to avoid redundancy.

In addition, many questions were complicated and unclear because of the way in which they were formulated (e.g. the question on 'Attitudes 
towards the French culture') or because they are in reality multiple questions (what was referred to as double questions in the analyses). The problem with double questions is that in some of the interviews, the interviewer chose to ask each part of the double question separately. In others, she chose to ask both parts from the outset. This lack of systematicity increased the data heterogeneity. Additionally, the interviewer had at times to remind the respondent of the part of the question that was left unanswered. Indeed, most question repetitions occurred with double questions partly because the questions were so complex that the respondents answered them only partially. According to Bell (2005, p. 141), double questions should be avoided in questionnaires as they can make interpretation difficult. Even though our interviews are semi-structured and allow a certain flexibility in question asking, we intend, in the main study, to avoid this question type with the targeted L2 learners in order to reduce question complexity. Furthermore, closed-ended questions were also problematic as going beyond a yes/no answer was highly dependent on the respondent. If the answer is judged as unsatisfactory by the interviewer, she has to ask further questions, and those questions also affect the quality of the gathered data (Romelaer, 2005) and are likely to make data interpretation difficult. Moreover, the lack of clarity of the questions was also due to the use of complex and unfamiliar words (e.g., the word anecdotes in the question related to 'Anecdotes about L2 use'), 
or of ambiguous vocabulary (e.g., travailler in the question on 'Investment in L2').

\section{Interview conducting and problem-solving strategies}

Our findings presented in section 5 confirm that the interviewer has to cope throughout the interviews with different types of problems. In the pilot study, these included problems related to the participants' L2 proficiency level and the capacity to anticipate lack of understanding. Without pretesting the different questions, it is quite difficult for the researcher to anticipate some of the potential comprehension problems.

To cope with the communication and comprehension problems, the interviewer used repetitions, reformulations and translations. Translations, which were minimally used as the participants rarely asked for them, were not always efficient in solving understanding problems. Reformulations were the most frequently used strategy to cope with perceived understanding difficulties. While helping to clarify the questions, they added to the heterogeneity of the data collected. In fact, many interviewer reformulations resulted in changes in the questions' orientation and scope, which consequently influenced the responses. Furthermore, while reformulating and repeating answers ensure the flow of the conversation, some of the interviewer's turns suggested possible answers to the respondents. These instances of bias show what the interviewer consciously or unconsciously would like to see in the data based on her research questions and objectives 
(Romelaer, 2005). What is vital in qualitative research, however, is that the researcher manages to keep 'a focus on learning the meaning that the participants hold about the problem or issue, not the meaning that the researchers bring to the research or that writers express in the literature' (Creswell, 2014, p. 234). Interviewer's subjectivity is evidently a problem and it can be hard to overcome as Bell $(2005$, p. 168) suggests :

Interviewing is not easy and many researchers have found it difficult to strike the balance between complete objectivity and trying to put the interviewee at ease. It is difficult to know how these difficulties can be overcome, though honesty about the purpose of the research and integrity in the conduct of the interview will all help.

Moreover, an interviewer's reaction to respondents' speech with expressions like oui and d'accord may also affect the neutrality that is expected in an interview. According to Romelaer (2005, p. 116), 'les 'oui...' ne doivent pas pouvoir être interprétés comme signifiant l'approbation donnée par l'interviewver aux propos du répondant, ou son étonnement sur les informations qu'il recueille.' These types of reactions, even though they are meant to encourage the participants, may also influence the respondents and produce the halo effect; i.e., "trying to please the researcher by giving the answers or responses they think are expected' (Mackey and Gass, 2005, p. 117).

\section{Conclusions}


To sum up, these observations confirm that interviewing is challenging, and a "skill" as put by Mackey and Gass (2005). Conducting effective semi-structured interviews requires practice and training. Pilot testing was fruitful, as it left us with a number of guidelines that are attuned to our population. Furthermore, it allowed us to uncover problems related to question wording and choice of items in the interview list. We could also assess the way the interviews were conducted and decide on the following measures that have been taken in the main study:

1. Extra careful attention was given to the wording of each question in order to avoid ambiguity and imprecision and consequently limit the respondents' need for reformulations and focus on giving relevant answers.

2. All background information questions were removed from the interview schedule. These questions were meant to collect information about the participants and to engage in a warm-up phase before talking about attitudes and opinions. These are no longer needed as part of the main interviews, as the participants are met before to complete other linguistic tasks. This helps to shorten the interview and to make it a more agreeable experience for the participants. Indeed, an hour-long interview in a L2 for language learners can be exhausting. In addition, the other closed-ended questions were also transformed into open questions in the main study. Finally, double questions were simplified so that each question referred to only one type of information and concept. All questions asked in the main 
study are open-ended and asked in a neutral and flexible way. For instance, to elicit data on 'Attitudes towards L2 culture', the question is reworded as follows: Parlez-moi de la culture française. Similar question wording is used in other questions (See Appendix 2) to facilitate talking about attitudes and opinions.

3. The interviewer should not be carried away by the flow of the conversation. As stated by Bell (2005, p. 161): 'an interview is more than just an interesting conversation. You need certain information and methods have to be devised to obtain that information, if at all possible.' In case the questions are unclear to the participants, clarifications attempts should be anticipated beforehand, not spontaneously formulated. According to Romelaer (2005, p. 118), 'la maîtrise des reformulations est un art difficile. D'abord elle impose une capacité d'attention très importante, ensuite, elle exige de savoir intervenir sans introduire de biais dans toute la mesure du possible.' Given these challenges, for each question, several alternative carefully worded reformulations should be prepared and included in the interview schedule. Additionally, a list of prompts should also be prepared for every question to obtain the most relevant answers possible.

4. The interviewer needs to be careful when reacting to the respondents' answers. Expressing approval should be minimal. Reformulation of answers should neither add extra information to what the informant has said nor should it influence this. 
5. The participants' L1 should not be completely discarded, as questions about feelings and opinions can be difficult to answer with a low L2 proficiency, even if the respondents are able to understand them. Indeed, open-ended questions require learners to engage in independent thinking (e.g. on attitudes) and they are generally not the type of questions that they are used to in university setting (Long and Sato, 1983) ${ }^{7}$ nor in administrative formalities. As such, the interview schedule of the main study contains questions in both languages. French L2 is used in the beginning of the interview then questions in Syrian Arabic are asked (e.g., a question on feelings about their life in France).

To sum up, in spite of the available literature on the way interviews should be conducted in general, the existing instructions and guidelines on how to conduct semi-structured interviews lacked precision and examples and were therefore insufficient for us in order to completely achieve our goals at the piloting phase. Additionally, every interview experience is unique because it is conducted with some specific research objectives and a special group of individuals. Also, every interview conducted with a different individual is also unique and presents the interviewer with a new set of challenges. The challenges encountered with the Syrian refugees and asylum seekers are numerous. The interviewer should be well-trained and prepared

\footnotetext{
${ }^{7}$ Long and Sato (1983) observe that the type of questions to which learners are exposed to in classroom setting are display questions (that require already known answers) as opposed to referential questions (that require that they engage in independent thinking).
} 
for all these types of problems and anticipate solutions to them. A good interview is one in which the respondents feel confident, speak freely and feel the need to tackle issues that are of major significance to them. Furthermore, our main objective is to be able to ask clear and completely accessible questions that elicit identical types of information from all respondents, generating a coherent set of on-topic and comparable data across individuals. For this reason, the interview type used in the main study is situated somewhere in between the rigidly structured type and the completely unstructured type of the continuum. Questions need to be open, clear, unambiguous, simply worded, and identically asked to all the respondents while at the same time allowing freedom and flexibility to both the interviewer and respondents.

9254 Words 


\section{References}

Adami, H., and André, V. (2015). Corpus et apprentissage du Français Langue d'Intégration (FLI). LINX, 68-69, 135-158.

Bell, J. (2005). Doing your own research. Berkshire: Open University Press.

Bremer, K., Broeder, P., Roberts, C., Simonot, M., and Vasseur, M.-T. (1993). Ways of achieving understanding. In C. Perdue (Éd.), Adult Language Acquisition: Cross-Linguistic Perspectives, Volume II: The Results (p. 153-195). Cambridge University Press.

Chaudron, C. (2003). Data collection in SLA research. In The Handbook of Second Language Acquisition (p. 762-828). Blackwell Publishers Ltd. Council of Europe. (2001). Common European Framework of Reference for Languages: Learning, teaching, assessment. Cambridge University Press.

Creswell, J. W. (2014). Research Design: Qualitative, Quantitative and Mixed Methods Approach. California: SAGE Publications.

Darvin, R., and Norton, B. (2015). Identity and a model of investment in applied linguistics. Annual Review of Applied Linguistics, 36-56.

Early, M., and Norton, B. (2012). Language learner stories and imagined identities. Narrative Inquiry, 22(1), 194-201.

Firth, A., and Wagner, J. (1997). On discourse, communication and (some) fundamental concepts in SLA Research. Modern Language Journal, $81(3), 285-300$. 
Gardner, R. C. (1985). Individual differences in second language achievement: focus on attitudes and motivation. In Social Psychology and Second Language Learning: The Role of Attitudes and Motivation (p. 39-61). Edward Arnold.

Hulstijn, J. H., Young, R. F., Ortega, L., Bigelow, M., DeKeyser, R., Ellis, N. C., Lantolf, J. P., Mackey, A., and Talmy, S. (2014). Bridging the gap: cognitive and social approaches to research in second language learning and teaching. Studies in Second Language Acquisition, 36(3), $361-421$.

Klein, W., and Perdue, C. (1992). Utterance Structure: Developing grammars again. Amsterdam/Philadelphia: John Benjamins Publishing Company.

Lantolf, J. P. (1999). Second culture acquisition. In E. Hinkel (Éd.), Culture in Second Language Teching and Learning (p. 28-46). Cambridge University Press.

Lantolf, J. P., and Thorne, S. L. (2007). Sociocultural theory and second language learning. In B. VanPatten and J. Williams (Éd.), Theories in second language acquisition (p. 201-224). Laurence Erlbaum.

Lantolf, J. P., Thorne, S. L., and Poehner, M. E. (2015). Sociocultural theory and second language development. In B. van Patten and J. Williams (Éd.), Theories in Second Language Acquisition (p. 207-226). Routledge. 
Long, M., M., and Sato, C. J. (1983). Classroom foreigner talk discourse: forms and functions of teachers. In Classroom Oriented Research in Second Languages (p. 268-285). Newbury House.

Mackey, A., and Gass, S. M. (2005). Second Language Research: Methodology and Design. Mahwah, New Jersey: Laurence Erlbaum Associates.

Mann, C. M., and Fazil, Q. (2006). Mental illness in asylum seekers and refugees. Primary Care Mental Health, 4, 57-66.

Miller, E. R., and Kubota, R. (2013). Second language identity construction. In J. Herschensohn and M. Young-Scholten (Éd.), The Cambridge Handbook of Second Language Acquisition (p. 230-250). Cambridge University Press.

Norton, B. (2000). Identity and Language Learning: Gender, Ethnicity and Educational Change. Pearson Education Limited.

Norton, B. (2013). Identity and Language Learning: Extending the Conversation. Essex, England: Multilingual Matters.

Norton, B., and Gao, Y. (2008). Identity, investiment, and Chinese learners of English. Journal of Asian Pacific Communication, 18(1), 109-120.

Norton, B., and Toohey, K. (2011). Identity, language learnbing, and social change. Language Teaching, 44(4), 412-446.

Norton Peirce, B. (1995). Social identity, investment, and language learning. Tesol Quarterly, 9-31. 
Oroujlou, N., and Vahedi, M. (2011). Motivation, attitude, and language learning. Procedia - Social and Behavioral Sciences, 29, 994-1000.

Pavlenko, A. (2001). How am I to become a woman in an American vein?: Transformations of gender performance in second language learning. In A. Blackledge, I. Piller, and M. Teutsch-Dwyer (Éd.), Multilingualism, Second Language Learning, and Gender (p. 133-174). Mouton de Gruyter.

Perdue, C. (Éd.). (1993a). Adult Language Acquisition: Cross-Linguistic Perspectives, Volume I, Field Methods. Cambridge: Cambridge University Press.

Perdue, C. (Éd.). (1993b). Adult Language Acquisition: Cross-Linguistic Perspectives, Volume II, The Results. Cambridge: Cambridge University Press.

Romelaer, P. (2005). Chapitre 4. L'entretien de recherche. In P. Roussel \& F. Wacheux (Éd.), Management des Ressources Humaines: Méthodes de Recherche en Sciences Humaines et Sociales (pp. 101-137). Louvain-laNeuve, Belgique: De Boeck Supérieur.

Sourisseau, J. (2018). Bilan du programme DILAMI, Dispositif Langues Accueil Migrants 2017 - 2018. L’Université Fédérale de Toulouse. https://www.univ-toulouse.fr/sites/default/files/2019-10/Bilanqualitatif-Dilami-2017-2018_UFTMP_1.pdf 
Tarone, E. (2007). Sociolinguistic approaches to second language acquisition research -1997-2007. The Modern Language Journal, 91(Focus Issue), 837-848.

Ushioda, E. (2003). Motivation as a socially mediated process. In D. Little, J. Ridley, and E. Ushioda (Éd.), Learner autonomy in theforeign language classroom: teacher, learner, curriculumand assessment (p. 90-102). Authentik Language Learning Resources Ltd.

Ushioda, E., and Dörnyei, Z. (2017). Beyond Global English: Motivation to learn languages in a multicultural world (Introduction to the special issue). Modern Language Journal, 101(3), 451-454.

van Hout, R. and Strömqvist, S. (1993). Measuring Language Acquisition: The influence of socio-biographical factors, in C. Perdue (Éd.), Adult Language Acquisition, , Volume I: Field Methods (p. 164-172). Cambridge University Press.

van Tubergen, F. (2010). Determinants of seond language proficiency among refugees in the Netherlands. Social Forces, 89(2), 515-534.

Véronique, G. D. (2013). Socialization. In J. Herschensohn and M. YoungScholten (Éd.), The Cambridge Handbook of Second Language Acquisition (p. 251-271). Cambridge University Press.

Vion, R. (2000). Compréhension et comportement communicatif. In A. Giacomi, H. Stoffel, and D. Véronique (Éd.), Appropriation $d u$ 
français par des marocains arabophones à Marseille: Bilan d'une recherche (p. 273-296). Publications de l'Université de Provence.

Vygotsky, L. S. (1986). Thought and Language. Massachusetts: MIT Press.

Young-Scholten, M. (2013). Low-educated immigrants and the social relevance of second language acquisition research. Second Language Research, 29(4), 441-454.

Zeinivand, T., Azizifar, A., and Gowhary, H. (2015). The relationship between attitude and speaking proficiency of Iranian EFL learners: The case of Darrehshehr city. Pocedia - Social and Behavioral Sciences, 199, 240-247. 


\section{Appendix 1: Pilot study interview schedule}

1. Âge

2. Sexe

3. Situation familiale

4. Pays d'origine

5. Statut en France / situation

6. Etudes antérieures

7. Métier, actuel ou antérieur

8. Langues parlées

9. Cours antérieurs de français

10. Avez-vous été aidé lors de votre arrivée en France?

11. Avez-vous des amis? Sont-ils Français?

12. Qu'est-ce qui vous plaît/déplaît en France?

13. Etes-vous en contact avec vos proches de votre pays d'origine? Par quels moyens?

14. Comment voyez-vous la culture française, donnez 3 choses qui la symbolisent (personnalités, monuments, livres, écrivains).

15. Que représente pour vous la France?

16. Comment voyez-vous les Français?

17. Quelles sont les différences entre la culture française et la vôtre?

18. Y-a-t-il des éléments de votre culture que vous souhaitez conserver? Pourquoi?

19. Plus tard est-ce que vous vous voyez rester ici?

20. Est-ce que vous suivez la politique en France?

21. Quelles sont les différences avec la politique dans votre pays d'origine?

22. Comment vous sentez-vous depuis que vous êtes en France?

23. Est-ce que quelque chose vous empêche de travailler comme vous le voudriez?

24. Est-ce que c'est plus ou moins difficile pour vous d'apprendre le français par rapport aux autres langues que vous avez apprises? Si oui, pourquoi?

25. Dans quelle langue parlez-vous avec vos enfants?

26. Quel niveau de langue pensez-vous avoir actuellement?

27. Qu'est-ce que l'apprentissage du français pourrait vous apporter?

28. À quelle fréquence travaillez-vous, où? [à nous de demander des détails en fonction de leur réponse]

29. Le français que vous étudiez au DEFLE est-il différent de ce que vous entendez à l'extérieur?

30. En classe, est-ce que vous participez/posez des questions? Si oui, à qui ? 
31. Comment se sont passés vos examens écrits/oraux? Étiez-vous assez préparé?

32. Au quotidien, à quelle fréquence parlez-vous français et avec qui?

33. Comment se passent vos interactions avec les Français?

34. Quelles expériences positives et négatives vous marquent en lien avec votre utilisation du français/racontez des anecdotes qui vont ont fait rire ou au contraire qui vous ont énervé en lien avec votre utilisation du français?

35. Lorsque vous écoutez la radio ou allumez la télévision, mettez-vous des ondes/chaînes arabes ou françaises? Lesquelles? 


\section{Appendix 2. Interview schedule reviewed*}

\begin{tabular}{|c|c|c|}
\hline \multicolumn{3}{|c|}{ 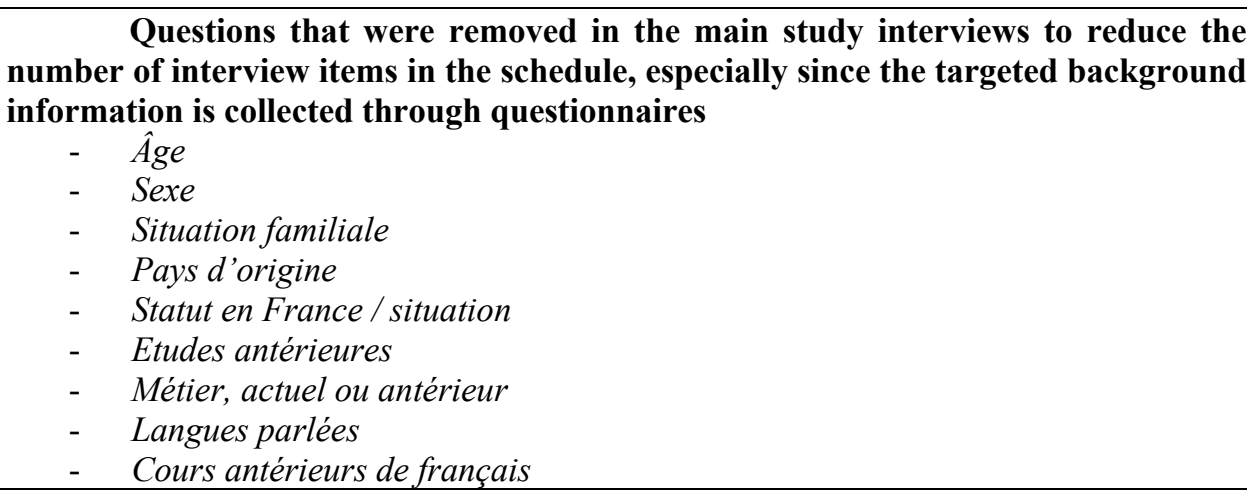 } \\
\hline \multicolumn{3}{|c|}{$\begin{array}{l}\text { Questions that were removed in the main study interviews because they were } \\
\text { of the Closed-ended and Closed-ended/Double type and they elicit short and } \\
\text { incomplete answers. } \\
\text { - Avez-vous été aidé lors de votre arrivée en France? } \\
\text { - Etes-vous en contact avec vos proches de votre pays d'origine? Par quels } \\
\text { - moyens? } \\
\text { - Elus tard est-ce que vous vous voyez rester ici? } \\
\text { - En classe, est-ce que vous participez/posez des questions? Si oui, à qui? }\end{array}$} \\
\hline \multicolumn{3}{|c|}{$\begin{array}{l}\text { Questions that were removed because they did not concern all the } \\
\text { participants } \\
\text { - Quelles sont les différences avec la politique dans votre pays d'origine? } \\
\text { - Dans quelle langue parlez-vous avec vos enfants? } \\
\text { - Est-ce que quelque chose vous empêche de travailler comme vous le voudriez? }\end{array}$} \\
\hline \multicolumn{3}{|c|}{ Questions revised for the main study interviews } \\
\hline \multirow{4}{*}{$\begin{array}{l}\text { Access and } \\
\text { interaction } \\
\text { opportunities in L2 }\end{array}$} & Questions & Rewording \\
\hline & $\begin{array}{l}\text { Avez-vous des amis? } \\
\text { Sont-ils Français? } \\
\text { Au quotidien, à quelle } \\
\text { fréquence parlez-vous } \\
\text { français et avec qui? }\end{array}$ & $\begin{array}{l}\text { 1. Parlez-moi de votre vie } \\
\text { sociale en France. }\end{array}$ \\
\hline & $\begin{array}{l}\text { Comment se passent } \\
\text { vos interactions avec les } \\
\text { Français? }\end{array}$ & \multirow[t]{2}{*}{$\begin{array}{l}\text { 2. Comment ça se passe pour } \\
\text { vous quand vous parlez } \\
\text { français? }\end{array}$} \\
\hline & $\begin{array}{l}\text { Quelles expériences } \\
\text { positives et négatives vous } \\
\text { marquent en lien avec votre } \\
\text { utilisation du } \\
\text { français/racontez des } \\
\text { anecdotes qui vont ont fait rire } \\
\text { ou au contraire qui vous ont } \\
\text { énervé en lien avec votre } \\
\text { utilisation du français? }\end{array}$ & \\
\hline
\end{tabular}




\begin{tabular}{|c|c|c|}
\hline & $\begin{array}{l}\text { Lorsque vous écoutez la radio } \\
\text { ou allumez la télévision, } \\
\text { mettez-vous des ondes/chaînes } \\
\text { arabes ou françaises? } \\
\text { Lesquelles? }\end{array}$ & $\begin{array}{l}\text { 3. Comment vous faites pour } \\
\text { pratiquer/parler le français? }\end{array}$ \\
\hline \multirow[t]{5}{*}{$\begin{array}{l}\text { Attitudes towards } \\
\text { the new } \\
\text { environment }\end{array}$} & $\begin{array}{l}\text { Comment voyez-vous la } \\
\text { culture française, donnez } 3 \\
\text { choses qui la symbolisent } \\
\text { (personnalités, monuments, } \\
\text { livres, écrivains). }\end{array}$ & \multirow[t]{3}{*}{$\begin{array}{l}\text { 4. Parlez-moi de la culture } \\
\text { française. }\end{array}$} \\
\hline & $\begin{array}{l}\text { Qu'est-ce qui vous } \\
\text { plaît/déplaît en France? }\end{array}$ & \\
\hline & $\begin{array}{l}\text { Que représente pour vous la } \\
\text { France? }\end{array}$ & \\
\hline & $\begin{array}{l}\text { Comment voyez-vous les } \\
\text { Français? }\end{array}$ & $\begin{array}{l}\text { 5. Qu'est-ce que vous pensez } \\
\text { des Français? }\end{array}$ \\
\hline & $\begin{array}{l}\text { Comment vous sentez-vous } \\
\text { depuis que vous êtes en France } \\
?\end{array}$ & $\begin{array}{l}\text { 6. Comment vous sentez-vous } \\
\text { en France? }\end{array}$ \\
\hline \multirow[t]{2}{*}{$\begin{array}{l}\text { Cultural sensitivity } \\
\text { and attachment }\end{array}$} & $\begin{array}{l}\text { Quelles sont les différences } \\
\text { entre la culture française et la } \\
\text { vôtre? }\end{array}$ & \multirow[t]{2}{*}{$\begin{array}{l}\text { 7. Quelles sont les différences } \\
\text { culturelles entre la France et la } \\
\text { Syrie? }\end{array}$} \\
\hline & $\begin{array}{l}\text { Y-a-t-il des éléments } \\
\text { de votre culture que vous } \\
\text { souhaitez conserver ? } \\
\text { Pourquoi? }\end{array}$ & \\
\hline \multirow{5}{*}{$\begin{array}{l}\text { Attitudes towards } \\
\text { L2 learning }\end{array}$} & $\begin{array}{l}\text { Est-ce que c'est plus ou moins } \\
\text { difficile pour vous } \\
\text { d'apprendre le français par } \\
\text { rapport aux autres langues } \\
\text { que vous avez apprises? Si } \\
\text { oui, pourquoi? }\end{array}$ & \multirow[t]{4}{*}{$\begin{array}{l}\text { 8. Parlez-moi de votre } \\
\text { expérience de l'apprentissage } \\
\text { du français. }\end{array}$} \\
\hline & $\begin{array}{l}\text { Quel niveau de langue pensez- } \\
\text { vous avoir actuellement? }\end{array}$ & \\
\hline & $\begin{array}{l}\text { Qu'est-ce que l'apprentissage } \\
\text { du français pourrait vous } \\
\text { apporter? }\end{array}$ & \\
\hline & $\begin{array}{l}\text { A quelle fréquence travaillez- } \\
\text { vous, où ? [à nous de } \\
\text { demander des détails en } \\
\text { fonction de leur réponse] }\end{array}$ & \\
\hline & $\begin{array}{l}\text { Le français que vous étudiez } \\
\text { au DEFLE est-il différent de } \\
\text { ce que vous entendez à } \\
\text { l'extérieur? }\end{array}$ & $\begin{array}{l}\text { 9. Qu'est-ce que la maîtrise de } \\
\text { la langue française pourrait } \\
\text { vous apporter }\end{array}$ \\
\hline
\end{tabular}




\begin{tabular}{|l|l|l|}
\hline $\begin{array}{l}\text { Comment se sont passés vos } \\
\text { examens écrits/oraux ? Étiez- } \\
\text { vous assez préparé ? }\end{array}$ & \\
\hline
\end{tabular}

*Only questions of the pilot study interview schedule are discussed here. The additional questions asked (e.g., questions in Syrian Arabic were not included). 